\title{
TRENDS IN THE SPATIAL DISTRIBUTION \\ OF CREATIVE ECONOMIES IN ROMANIA
}

DOI: http://dx.doi.org/10.18509/GBP.2019.46

UDC: $338.46: 33(498)$

\author{
Andreea Karina Gruia ${ }^{1,2}$ \\ Alexandra Grecu ${ }^{1,2}$ \\ Marian Marin ${ }^{1,2}$ \\ Elena-Alisa Predescu ${ }^{1,2}$ \\ Camelia Teodorescu ${ }^{1,2}$ \\ ${ }^{1}$ University of Bucharest - Faculty of Geography, Romania \\ ${ }^{2}$ University of Bucharest - Research Center for Integrated Analysis and Territorial \\ Management (CAIMT), Romania
}

\begin{abstract}
Today, creative economies are the determinants of economic growth. Creative economies play an important role in promoting innovation across the economy, both through their products and services, as well as through new ideas, knowledge, processes and ways of working. Terms of innovation and creativity are increasingly used in many national development strategies. The concept of creative economy was derived from the concept of innovation. The study aims to analyze the spatial distribution of creative economies at national level. In order to quantify the spatial dynamics of the creative economies in Romania, was created a database, at the level of administrative-territorial unit, with 2 economic indicators - the number of employees and the turnover, according to the NACE classification (Classification of National Economy Activities), on the basis of which have been made distribution maps of creative economies. This study focuses on the period from 2000 to 2016. The database was also used to achieve evolution graphs of above mentioned indicators, at the four-digit NACE code. This study has produced spatial patterns of creative economies that have highlighted the fact that spatial agglomerations of creative activities are located around the great urban concentration.
\end{abstract}

Keywords: creative economies, territorial systems, national distribution, spatial patterns

\section{INTRODUCTION}

The term "creative economy" has attracted attention all over the world. The creative economy can be defined as a policy that aims to generate a new growth through economic operations that promote creativity, convergence of knowledge and advanced science technology based on coordinated learning, thereby creating new markets and new jobs. This can be understood as a new development that has evolved beyond the pursued and imitated economic model, which has been followed by most developing countries so far [1].

The creative sector plays an important role in spreading innovation across the economy with the help of the products and services offered, but also through the spread of new ideas, knowledge, processes and new ways of working. Also, with their help, social inclusion is supported, encouraging the inclusion of cultural diversity and promoting human development [2]. 
The strengths of the creative economy are related to the fact that the creative industries are not limited to an elite of artists or trained firms, they comprise (or can encompass) everyone, they are not confined to a sector of the economy, they characterize (or can characterize) the whole economy and they are not a feature of advanced or rich countries, creative industries are (or could be) everywhere [3], [4].

The set of economic, social, structural and economic and financial crises have affected the various creative industries, including entrepreneurial activities [5]. However, due to the heterogeneity of creative industries, the effects of the crisis have not been felt in some creative activities such as information and communication activities [6]. Studies have shown that the creative sector, generally, has been more resistant to the global economic crisis than other economic sectors [2]. A reason for the resilience of the creative sector in times of turbulence may be related to their ability to form specific production areas or socalled creative clusters. The creative cluster is considered to be a tool that can stimulate the development of the creative economy through the transmission of information, knowledge sharing, interactions and the necessary infrastructure [7].

\section{METHODOLOGY}

The analysis of the distribution and dynamics of the creative economies in Romania was achieved by creating an economic database at the level of the administrative-territorial unit with 2 economic indicators (number of employees and turnover) for the creative economic activities according to the National Classification of Economic Activities (NACE), at the four-digit level for the period 2000-2016. They were selected 46 codes from the NACE list, considered appropriate by the authors to highlight the creative sector (Table 1).

Table 1. Classification of NACE codes who belong to creative activities

\begin{tabular}{|c|c|c|c|}
\hline \begin{tabular}{|l} 
NACE \\
CODES \\
\end{tabular} & ECONOMIC ACTIVITIES & $\begin{array}{c}\text { DOMAIN } \\
\text { ACTIVITY } \\
\end{array}$ & $\begin{array}{c}\text { BUSINESS } \\
\text { LINE }\end{array}$ \\
\hline 1811 & Printing of newspapers & \multirow{4}{*}{$\begin{array}{c}\text { MANU- } \\
\text { FACTURING }\end{array}$} & \multirow{4}{*}{$\begin{array}{l}\text { SECONDARY } \\
\text { SECTOR }\end{array}$} \\
\hline 1812 & Other printing & & \\
\hline 1813 & Pre-press and pre-media services & & \\
\hline 1814 & Binding and related service & & \\
\hline 5811 & Book publishing & \multirow{24}{*}{ 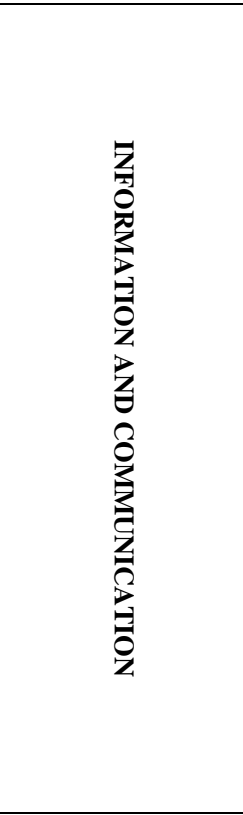 } & \multirow{26}{*}{ 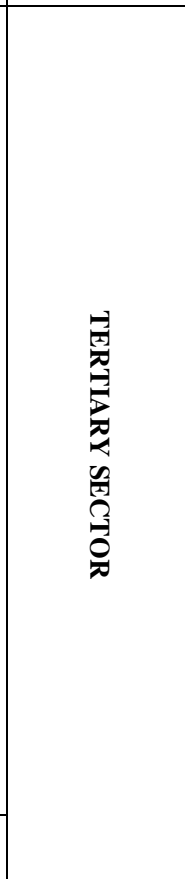 } \\
\hline 5812 & Publishing of directories and mailing lists & & \\
\hline 5813 & Publishing of newspapers & & \\
\hline 5814 & Publishing of journals and periodicals & & \\
\hline 5819 & Other publishing activities & & \\
\hline 5821 & Publishing of computer games & & \\
\hline 5829 & Other software publishing & & \\
\hline 5911 & Motion picture, video and television programme production activities & & \\
\hline 5912 & Motion picture, video and television programme post-production activities & & \\
\hline 5920 & Sound recording and music publishing activities & & \\
\hline 6010 & Radio broadcasting & & \\
\hline 6020 & Television programming and broadcasting activities & & \\
\hline 6110 & Wired telecommunications activities & & \\
\hline 6120 & Wireless telecommunications activities & & \\
\hline 6130 & Satellite telecommunications activities & & \\
\hline 6190 & Other telecommunications activities & & \\
\hline 6201 & Computer programming activities & & \\
\hline 6202 & Computer consultancy activities & & \\
\hline 6203 & Computer facilities management activities & & \\
\hline 6209 & Other information technology and computer service activities & & \\
\hline 6311 & Data processing, hosting and related activities & & \\
\hline 6312 & Web portals & & \\
\hline 6391 & News agency activities & & \\
\hline 6399 & Other information service activities n.e.c. & & \\
\hline 7111 & Architectural activities & \multirow{2}{*}{$\begin{array}{l}\text { PROFESSIONAL } \\
\text { SCIENTIFIC AND } \\
\end{array}$} & \\
\hline 7112 & Engineering activities and related technical consultancy & & \\
\hline
\end{tabular}




\begin{tabular}{|c|c|c|}
\hline 7120 & Technical testing and analysis & \multirow{8}{*}{$\begin{array}{l}\text { TECHNICAL } \\
\text { ACTIVITIES }\end{array}$} \\
\hline 7311 & Advertising agencies & \\
\hline 7312 & Media representation & \\
\hline 7320 & Market research and public opinion polling & \\
\hline 7410 & Specialised design activities & \\
\hline 7420 & Photographic activities & \\
\hline 7430 & Translation and interpretation activities & \\
\hline 7490 & Other professional, scientific and technical activities n.e.c. & \\
\hline 9001 & Performing arts & \multirow{8}{*}{$\begin{array}{c}\text { ARTS } \\
\text { ENTERTAINMENT } \\
\text { AND RECREATION }\end{array}$} \\
\hline 9002 & Support activities to performing arts & \\
\hline 9003 & Artistic creation & \\
\hline 9101 & Library and archives activities & \\
\hline 9311 & Operation of sports facilities & \\
\hline 9312 & Activities of sports clubs & \\
\hline 9313 & Fitness facilities & \\
\hline 9319 & Other sports activities & \\
\hline
\end{tabular}

Based on the data used, were created four maps for each indicator, using open-source software QGIS 3.4, representing the years: 2000 (the reference year), 2008 (the year of the economic crisis), 2009 (the year when the effects of the economic crisis are noticed) and 2016 (the last year analyzed). Based on the sequential color scheme (the intensity of the color increases with the value of the indicator), the maps reveal gradually the evolution of Romania's turnover and the number of employees in the creative sector.

\section{RESULTS AND DISCUSSIONS}

Based on the data used, were created four maps for each indicator, using open-source software QGIS 3.4, representing the years: 2000 (the reference year), 2008 (the year of the economic crisis), 2009 (the year when the effects of the economic crisis are noticed) and 2016 (the last year analyzed). Based on the sequential color scheme (the intensity of the color increases with the value of the indicator), the maps reveal gradually the evolution of Romania's turnover and the number of employees in the creative sector.

Analyzing the distribution of the total turnover (Fig.1) it can be observed a positive trend with an evolution over the 4 years analyzed. Thus, for the year 2000 (Fig. 1A), is observed the concentration of the turnover in the big cities as: Bucharest (with a maximum of 5.739.656.152 lei) followed by Timişoara, Cluj-Napoca, Braşov, Constanţa, Ploieşti, Iaşi and Sibiu.

The highest values for the year 2000 were recorded in the field of Information and Communication, respectively the NACE code 6120, representing Wireless telecommunications activities. The year 2008 (Fig. 1B) shows an increase in the total turnover, with a higher concentration of the creative economies on the territory of the country, the highest value recorded by the city of Bucharest followed by Cluj-Napoca, Timişoara, Ploiești, Iași, Braşov, Voluntari and Constanţa. The main directions of growth are in the activities of architecture, software, publishing and printing and information technology consultancy. The year 2009 (Fig. 1C) registered a slight decrease, against the background of the economic crisis, but the city that has the monopoly over the creative activities is Bucharest (maximum value of 15.575.305.303 lei). Compared to the first year of the analysis, 2016 marks a positive trend in development of total number of turnover in the creative sector. Throughout the analyzed period, Bucharest is the city with the highest turnover values. For the year 2016 (Fig. 1D), Bucharest has $69.20 \%$ of the total turnover in the creative sector, followed by Cluj-Napoca Timișoara, Iași, Voluntari, Brașov and Ploiești. 


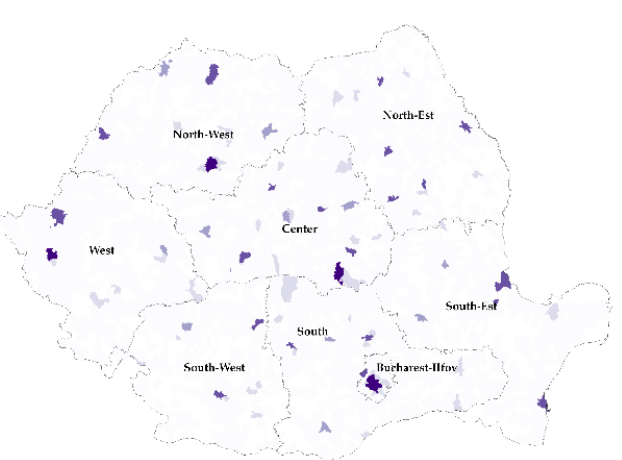

A

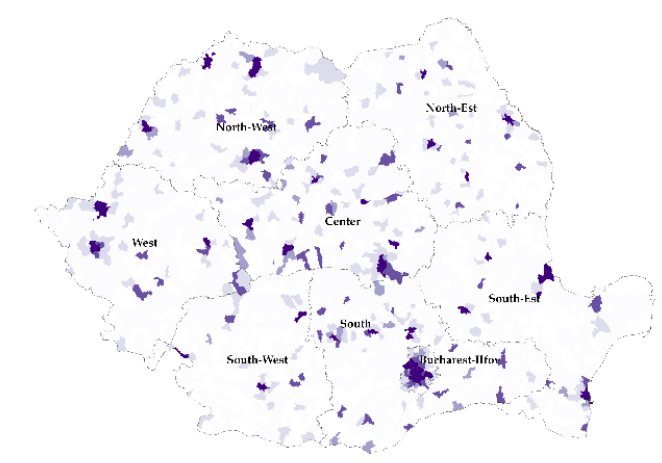

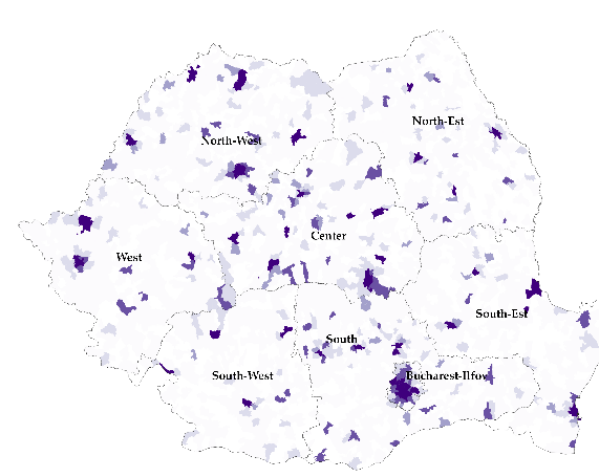

B

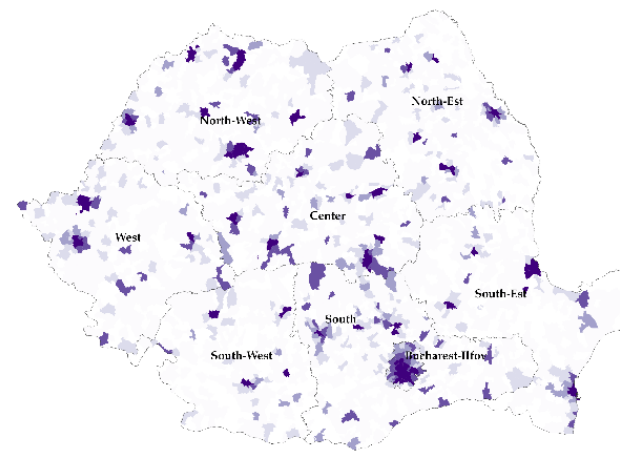

C

$$
\begin{gathered}
\text { D } \\
<1000000 \\
1000000-5000000 \\
5000000-10000000 \\
10000000-60000000 \\
>60000000
\end{gathered}
$$

Figure 1. Distribution of total turnover - A (2000), B (2008), C (2009), D (2016)

The most important programs that supported the development of the creative economy were the "Governmental Strategy for the Development of the SME (Small and Medium Enterprises) Sector and the Improvement of the Romanian Business Environment", which identifies national sectors with potential for increasing SME competitiveness, regional strategies which identifies regional sectors with potential for increasing competitiveness, which was subjected to public consultation in 2014. Also, in the Decision no. 775/2015 on the approval of the "National Competitiveness Strategy 2015-2020" are present the creative sectors in the economic sectors with a competitive potential and an important economic and employment-related role.

In order to be able to graphically represent the evolution of the total number of turnover (Fig. 2), the values were divided into 10.000 lei. The graph shows an upward trend in turnover, with a value of 6.758.678.232 lei in 2000, contributed by basic activities such as advertising, architecture, newspaper printing and telecommunications. 


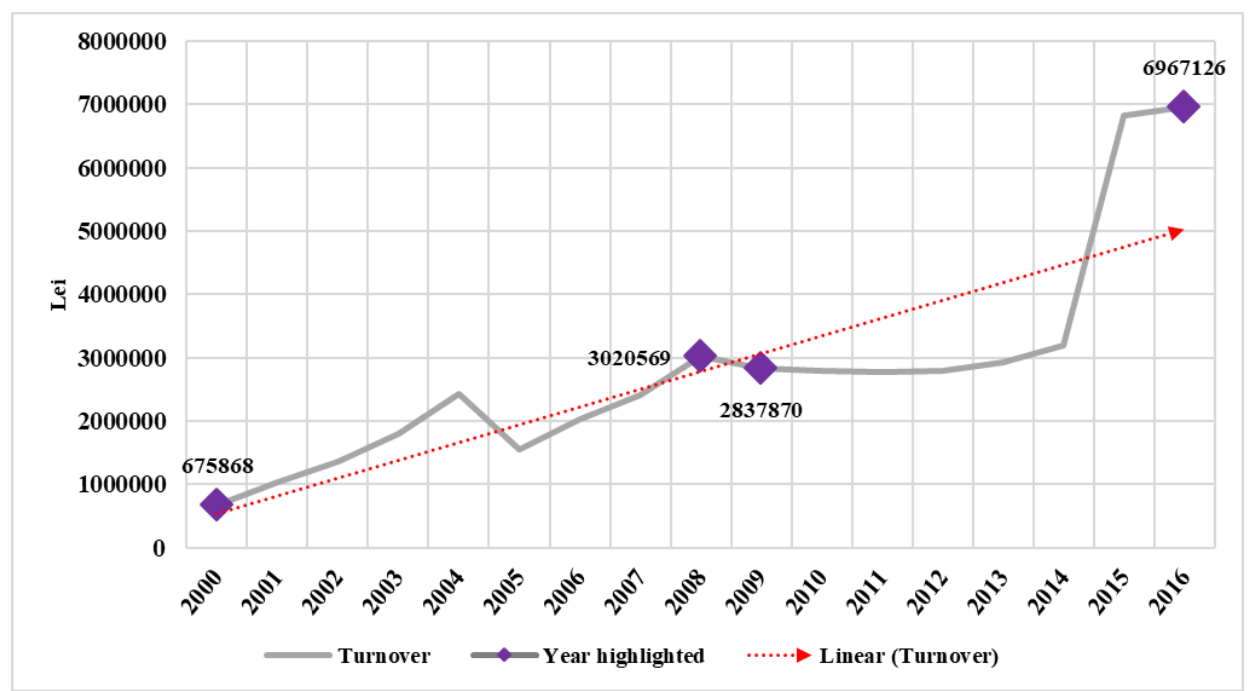

Figure 2. Evolution of total turnover (/10.000 lei)

A value of 30,205,691,631 lei is registered in 2008 and besides the basic activities that are remarkable in the creative industry, is detached IT activities as computer programming activities - NACE code $\mathbf{6 2 0 1}$ and computer consultancy activities - NACE code 6202. Against the background of the economic crisis, were observed slight decreases of turnover in 2009, reaching a value of 28.378.700.369 lei. The creative sector registers lower decreases than other economic sectors due to areas of activity that are more commercially traded than other activities in other economic sectors. After 2009, there is a stagnation of values until 2014 when there is an increase, reaching in 2015 to a value of 68.343.201.116 lei, with a slightly increasing until 2016 (maximum value of 69.671.264.198 lei). The growth after 2014 is driven by favorable policies that have encouraged the development of creative activities, especially in the IT field. Domain that has as its main business objective the development of software products with many more segments than other services, which mainly develops for foreign customers and has an increase in the absorption of European funds.

The above graphical panel presents, for the 4 years analyzed, a classification of the first 10 CAEN codes that is highlighted in the analysis of turnover. In order to be able to graphically represent the total turnover (Fig. 3), the values were divided into 10.000 lei. It is highlighted for the year 2000 (Fig. 3A) NACE code - 6110 - Wired telecommunications activities, activity that sums a value of 1.994.411.206 lei, for year 2008 (Fig. 3B) NACE code $\mathbf{7 1 1 2}$ - Engineering activities and related technical consultancy, with a value of 3.548.364.610 lei, for year 2009 (Fig. 3C) NACE code $\mathbf{6 2 0 1}$ - Computer programming activities, with a value of 3.411.451.218 lei and for year 2016 (Fig. 3D) NACE code - $\mathbf{6 1 2 0}$ - Wireless telecommunications activities, with a maxim value for the analyzed of 11.636.206.066 lei. The predominant activities for the analyzed years are from field IT, advertising, publishing and printing, cinema and video and architecture. In 2008 it joins activities as media and TV and in 2009 new activities as video game and video game testing. 

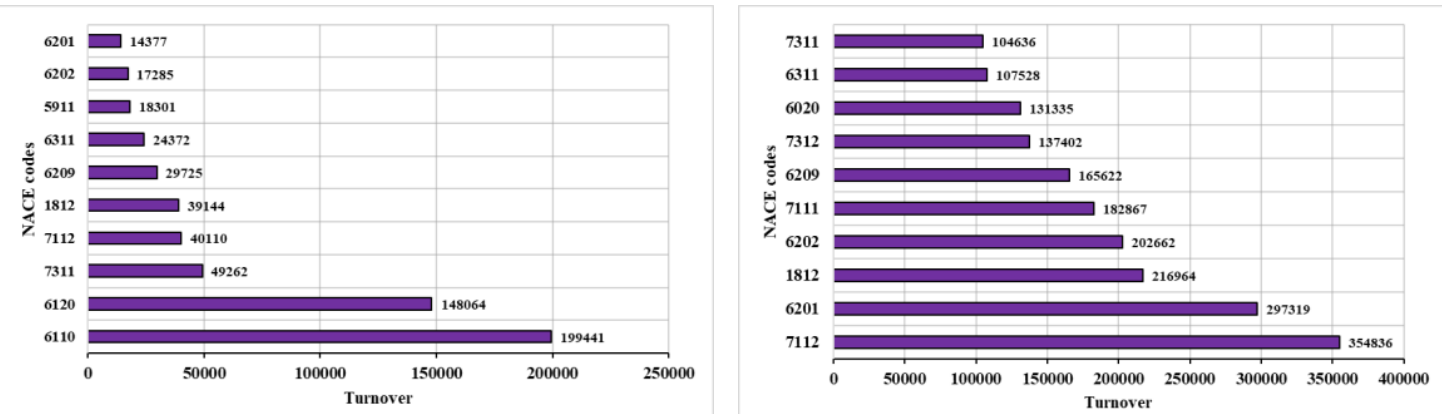

A

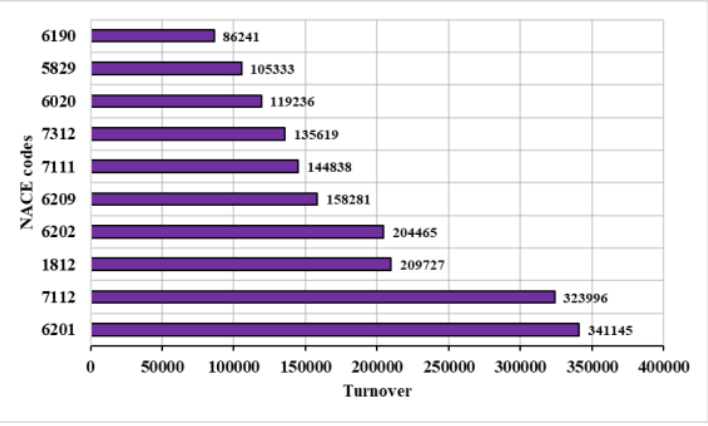

C

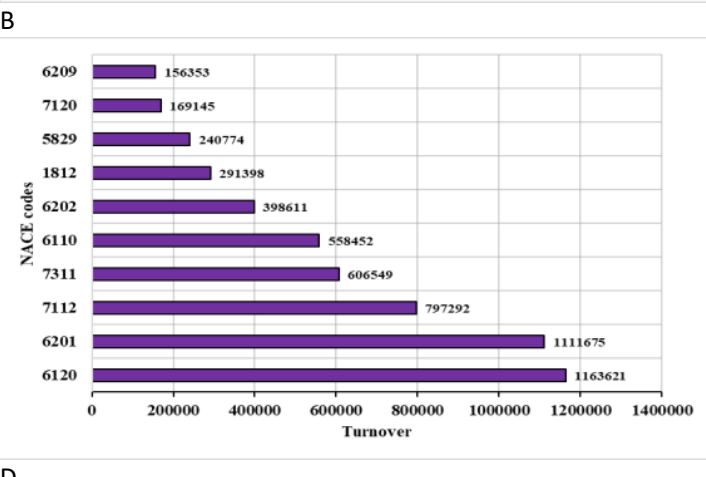

Figure 3. Evolution of the first 10 creative CAEN codes for the turnover - A (2000), B (2008), C (2009) and D (2016) (/10.000 lei)

The trend is a positive one because of software activities that have a dynamic and growth potential much faster than other activities in other sectors.

The evolution of the number of employees in the creative sector (Fig. 4) highlights the fact that creative activities are concentrated in and around the big cities. Analyzing the polarization of the creative industries by the number of employees for the year 2000 (Fig. 4A), it can be observed a concentration of employees in cities such as Bucharest (with a maximum of 83.051 employees), Timișoara (with 37.947 employees), Cluj-Napoca (2.659 employees), Ploieşti and Constanţa with 2.374, respectively 2.286 employees. Most employees are located in IT field (NACE code - 6110 - Wired telecommunications activities and 6202 - Computer consultancy activities) and architecture (NACE code 7112 - Engineering activities and related technical consultancy).

Analyzing the year 2008 (Fig. 4B) there is an evolution of the employees, having as its main pole of concentration the city of Bucharest with 159.052 employees followed by Cluj-Napoca with 12.307 employees, Timișoara with 10.191 employees, Brașov with 7.012, and Iași with 6.732 employees. The areas that focus a significant number of employees are architecture - $\mathbf{7 1 1 2}$ - Engineering activities and related technical consultancy, and IT - 6110 - Wired telecommunications activities and 6201 - Computer programming activities. In 2009 (Fig. 4C) there is a slight decrease on the background of the economic crisis but with the same five cities that have the monopoly on the creative sector, respectively Bucharest with 163.021 employees, Cluj-Napoca 11.759 employees, Timişoara with 10.192 employees, Braşov and Iași with 6.476 and respectively 5.904 employees, the fields of activity being the same. 

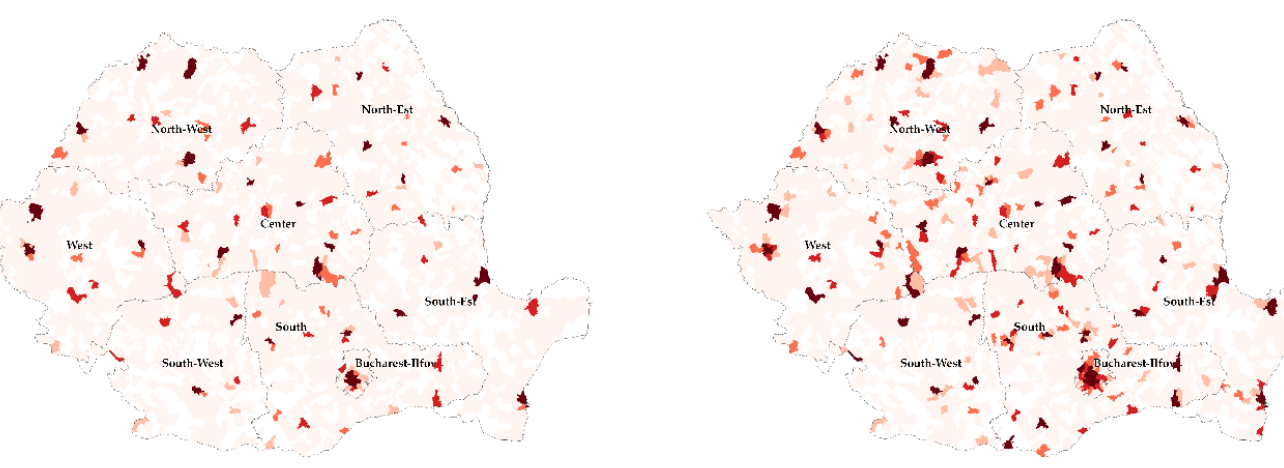

A

B
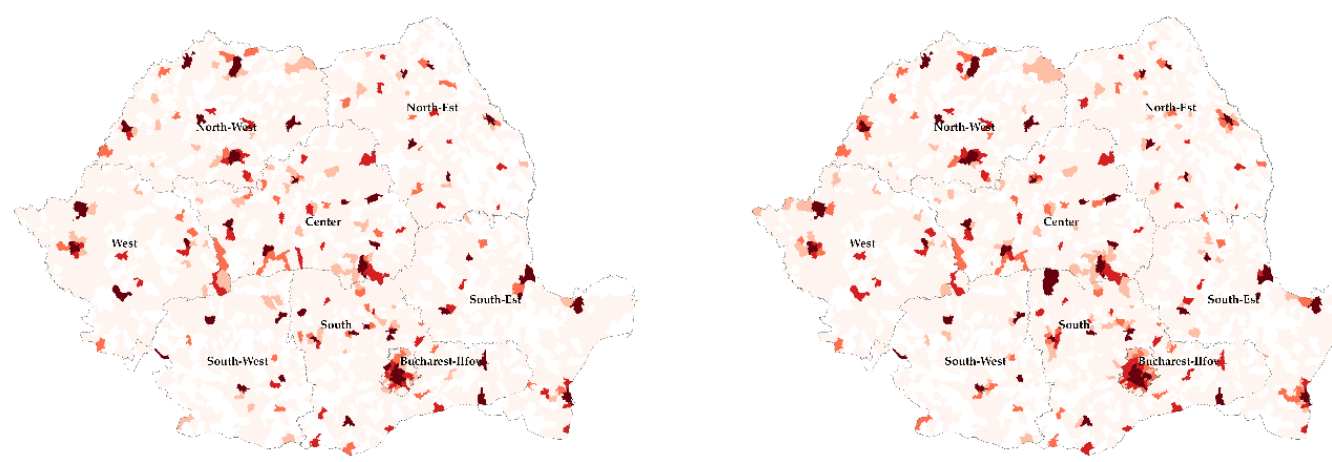

C

$$
\begin{aligned}
& \multicolumn{1}{c}{\mathrm{D}} \\
&<25 \\
& 25-50 \\
& 50-100 \\
& 100-400 \\
& \square
\end{aligned}
$$

Figure 4. Distribution of the number of employees - A (2000), B (2008), C (2009), D (2016)

For the year 2016 (Fig. 4D) there is a decrease in the number of employees in the creative sector with the highest values in the main cities such as Bucharest (143.467 employees), Cluj-Napoca (22.396 employees), Timişoara (10.778 employees), Iași (9.575 employees) and Braşov (7.304 employees). As regards the spatial distribution at national level, the first 4 cities in where are located IT companies are: Bucharest, Cluj-Napoca, Timişoara and Braşov. The creative sector has a positive impact on the employment rate, increasing productivity and industrial innovation thanks also, to numerous successful start-ups.

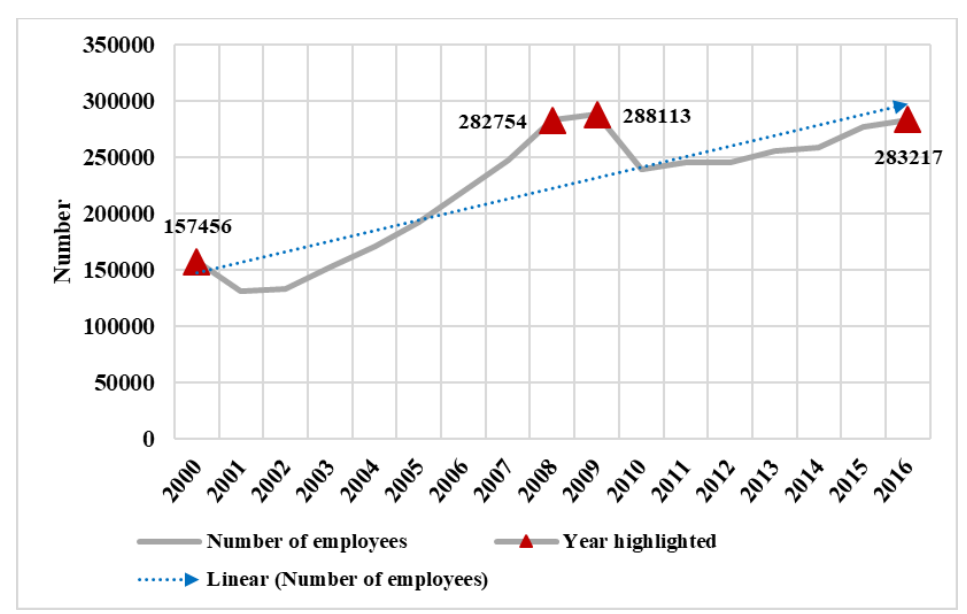

Figure 5. Evolution of the total number of employees 
Analyzing the graph showing the evolution of the number of employees for the period 2000-2016, it can be observed an upward trend with an increase until 2009, followed by a decrease as a result of the economic crisis in 2008 and a slight increase until 2016. For the analyzed years, the creative activities that involve a significant number of employees are architecture (7112 - Engineering activities and related technical consultancy) and IT (6110 - Wired telecommunications activities and 6201 - Computer programming activities). At the national level, 2000 is represented by 157.456 employees in the creative sector, for 2008 are reported 282.754 employees, a growth and a maximum in 2009 with 288.133 employees and 283.217 employees for the year 2016 .

Employees growth in the creative sector is also based on the existence of numerous programs and projects that encourage the creation of start-ups as well as the number of successful start-ups.

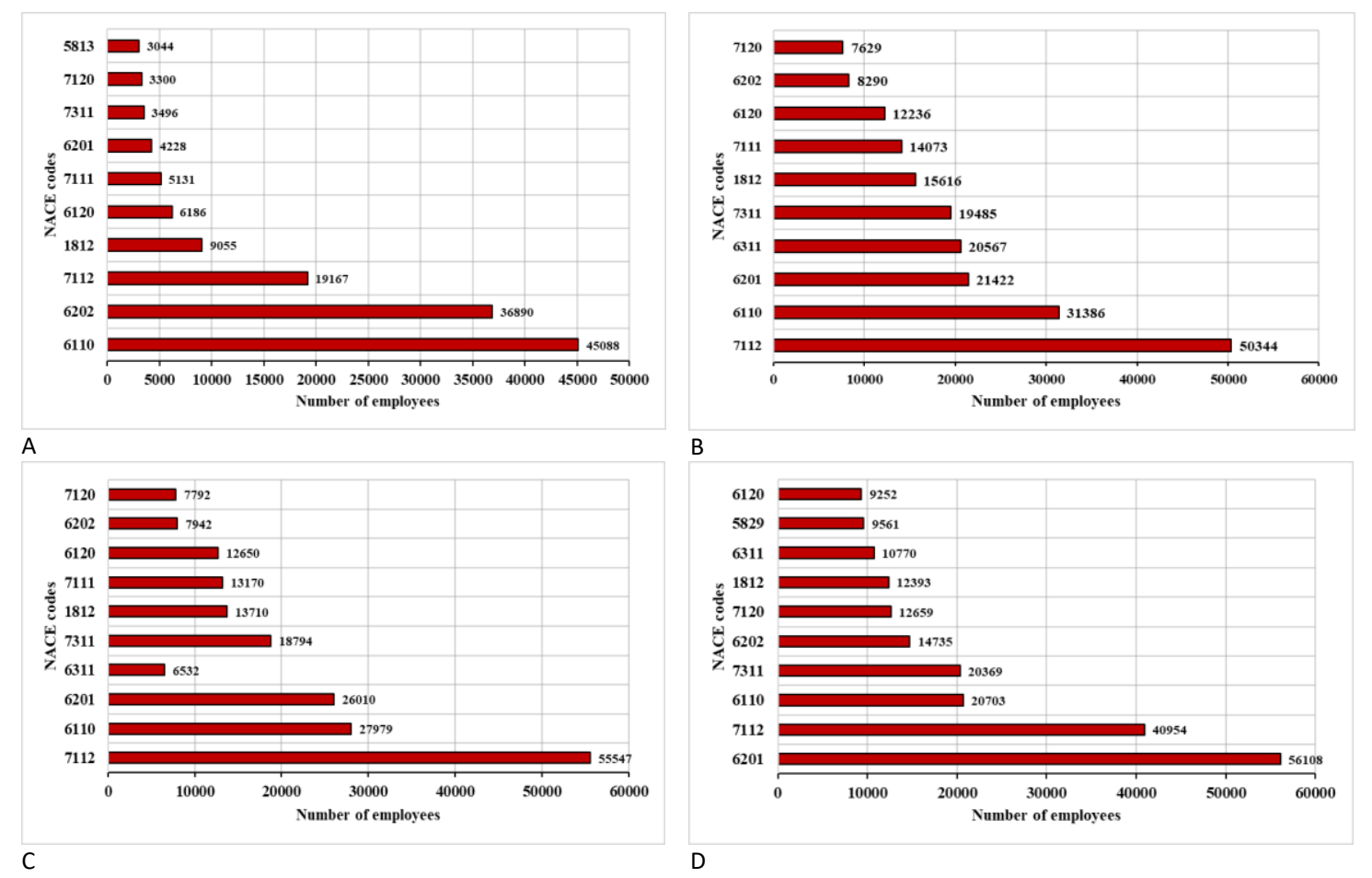

Figure 6. Evolution of the first 10 creative CAEN codes for the number of employees - A (2000), B (2008), C (2009) and D (2016)

Analyzing the classification of the first 10 NACE codes that are highlighted in the evolution of the number of employees, it can be observed for the year 2000 (Fig. 6A) NACE code 6110 - Wired telecommunications activities, an activity which totals 45.088 employees in the creative sector, being followed by $\mathbf{6 2 0 2}$ - Computer consultancy activities with a value of 36.890 employees. Year 2008 (Fig. 6B) shows a hierarchy with architectural activities at the forefront of classification, NACE code 7112 - Engineering activities and related technical consultancy with a number of 50.344 employees being followed by the two IT codes, 6110 - Wired telecommunications activities and $\mathbf{6 2 0 1}$ Computer programming activities with 31.386 employees and, respectively 21.422 employees. For the year 2009 (Fig. 6C) the picture is the same, with the predominance of the 3 codes but with slightly increasing values for NACE code 7112 - 55.547 employees and NACE code $\mathbf{6 2 0 1}$ with 26.010 employees and a slight decrease for NACE code $\mathbf{6 1 1 0}$ with 27.979 employees. The hierarchy for 2016 (Fig. 6D) shows a constant for $\mathbf{6 2 0 1}$ with 
56.108 employees, 7112 - 40.954 employees and $\mathbf{6 1 1 0}$ with 20.703 employees, with decreases observed for architectural activities and significant increases for IT.

The activities that are at the forefront of the hierarchy for the years analyzed are IT and architecture followed by editing and printing, advertising, testing and analysis and games and testing of video games. In 2008, it joins written and oral translation activities, and in 2009 new activities as data processing, web site administration and related activities.

The trend is an upward trend, the number of employees is on the increase, the activities at the forefront of classification remain constant for the 4 years, respectively architectural activities that are basic activities for the creative industries and IT industry, an area that grows and develops on all levels, thus faster than other economic sectors.

The results obtained in this study offer new directions in the analysis of the role of creative economies in the development of both local and regional economy in Romania.

The paper complements previous studies on the dynamics of the economic profile of the creative sector [8], [9], [10], [11] and supports the idea that creative economies rethink culture as a driver of regional and national development and are generating functional complexity [8], [9], [11]. The methodology used is a complement to previous studies and makes a special contribution to the analysis of functional complexity in the local, regional and national economy [10], [12], [13], [14], [15].

\section{CONCLUSIONS}

The study has generated spatial patterns of creative economies that have highlighted the fact that the spatial agglomerations of creative activities are located around the great urban concentration, placing Bucharest in the first place, both in terms of turnover and number of employees.

The creative sector has begun to play an important role in the national economy, with a significant contribution, with a share of $6.22 \%$ of turnover in $2000,4.47 \%$ in $2008,4.37 \%$ in 2009 , and with a value of $4.78 \%$ of the turnover of the total economy in 2016. As regards the employees, the economic picture shows a share of $3.97 \%$ for the year 2000 , $5.78 \%$ for $2008,6.11 \%$ for in 2009 and with a value of $11.14 \%$ of employees in the total economy for the year 2016.

The analysis reveals a positive trend for IT and its related activities, so there is an increasing number of employees trained in this area and the turnover is steadily increasing and it is highlighted that this sector has grown as a dimension and pursues a continues to develop in the coming years.

The creative sector in Romania is becoming one of the main drivers of the growth of the national economy, being a sector with a strong activity and a visible dynamic from year to year thanks to existing national programs such as Start-up Nation and Creative START but also through "Government Strategy for SME Development and Improvement of Business Environment in Romania","National Strategy for Competitiveness 2015-2020" and the Creative Romania Finance Line (June 2016), which is financed by the European Social Fund, the Creative Romania Program and is dedicated to supporting entrepreneurship in the cultural and creative sectors.

Due to the positive impact of creative industries on growth and economic development, they are an important target group for the development of cities and regions. 


\section{REFERENCES}

[1] Sung T. K. The creative economy in global competition, Technological Forecasting \& Social Change, vol. 96, pp 89-91, 2015.

[2] United Nations. Creative economy report 2010. Creative economy: A feasible development option, 2011. Accessed February 17, 2018, from http://unctad.org/en/Docs/ditctab20103_en.pdf

[3] Boccellaa N. \& Salernob I. Creative Economy, Cultural Industries and Local Development, Procedia - Social and Behavioral Sciences, vol. 223, pp 291-296, 2016.

[4] Hartley J., Wen W. \& Siling Li H. Creative Economy and Culture Challenges, Changes and Futures for the Creative Industries, 2014 In Boccellaa N. \& Salernob I. Creative Economy, Cultural Industries and Local Development, Procedia - Social and Behavioral Sciences, vol. 223, pp 291-296, 2016.

[5] De Propris L. How are creative industries weathering the crisis?, Cambridge Journal of Regions, Economy and Society, vol. 6, pp 23-35, 2013.

[6] Pratt A. C. \& Hutton T. A. Reconceptualising the relationship betwen the creative economy and the city: Learning from the financial crisis, Cities, vol. 33, pp 86-95, 2013.

[7] Musterd S., \& Murie A. Making competitive cities, Oxford: Wiley-Blackwell, 2010 In Boccellaa N. \& Salernob I. Creative Economy, Cultural Industries and Local Development, Procedia - Social and Behavioral Sciences, vol. 223, pp 291-296, 2016.

[8] Stoian D., Peptenatu D., Pintilii R. D. \& Schvab A. Territorial Distribution of Creative Poles in Romania, Procedia Social and Behavioral Sciences, vol. 122, pp 184-188, 2014.

[9] Pintilii R. D., Braghina C., Draghici C. C. \& Saghin I. Territorial imbalances in the distribution of the creative industries in the North-Eastern Development Region, Procedia Social and Behavioral Sciences, vol. 122, pp 179-183, 2014.

[10] Peptenatu D., Draghici C. \& Merciu C. Characteristics of entrepreneurial profile in some emergent territorial structures in Romania, Actual problems of economics, vol. 138, pp 448-458, 2012.

[11] Pintilii R. D., Peptenatu D., Ciobotaru A. M., Toma S. G., Grigore A. M., Drăghici C. C., Dobrea R. C., Simion A. G., Andronache I., Teodorescu C. \& Diaconu C. D. Creative economies in Romania - spatial projections and trends, Bulletin of Geography. Socio-economic Series, vol. 37, pp 95-108, 2017.

[12] Peptenatu D., Merciu C., Merciu G., Drăghici C. \& Cercleux L. Specific features of environment risk management in emerging territorial structures, Carpathian Journal of Earth and Environmental Sciences, vol. 7, pp 135-143, 2012.

[13] Peptenatu D., Drăghici C., Stoian D., Pintilii R. D., Cercleux A. L., Merciu C. \& Schvab A. Qualitative changes in the entrepreneurial sector in emerging territorial systems - Craiova case study, Acta Geographica Slovenica-Geografski Zbornik, vol. 54, pp 293-304, 2014.

[14] Andronache I., Peptenatu D., Ciobotaru A. M., Gruia A. K. \& Gropoşilă N. M. Using Fractal Analysis in Modeling Trends in the National Economy, Procedia Environmental Sciences, vol. 32, pp 344-351, 2016.

[15] Ianos I., Peptenatu D., Pintilii R. D. \& Draghici C. About susteinable development of the territorial emergent structures from the metropolitan area of Bucharest, Environmental Engineering and Management Journal, vol. 11, pp 1535-1545, 2012. 